\title{
Methylobacterium variabile sp. nov., a methylotrophic bacterium isolated from an aquatic environment
}

\author{
Virginia Gallego, Maria Teresa García and Antonio Ventosa \\ Department of Microbiology and Parasitology, Faculty of Pharmacy, University of Sevilla, \\ 41012 Sevilla, Spain
}

Correspondence

Antonio Ventosa

ventosa@us.es

\begin{abstract}
Strain $\mathrm{GR}^{\top}{ }^{\top}$ was isolated from drinking water during a screening programme to monitor the bacterial population present in the distribution system of Seville (Spain), and it was studied phenotypically, genotypically and phylogenetically. This pink-pigmented bacterium was identified as a Methylobacterium sp. Members of this genus are distributed in a wide variety of natural habitats, including soil, dust, air, freshwater and aquatic sediments. Phylogenetic analysis of the 16S rRNA gene sequence showed that strain $\mathrm{GR3}^{\top}$ was closely related to Methylobacterium aquaticum (97.4\% sequence similarity), whereas sequence similarity values with respect to the rest of the species belonging to this genus were lower than $96 \%$. Furthermore, the DNA-DNA hybridization data and its phenotypic characteristics clearly indicate that the isolate represents a novel Methylobacterium species, for which the name Methylobacterium variabile sp. nov. is proposed. GR3 ${ }^{\top}\left(=\mathrm{DSM} 16961^{\top}=\mathrm{CCM} 7281^{\top}=\right.$ CECT $\left.7045^{\top}\right)$ is the type strain; the DNA G + C content of this strain is $69 \cdot 2 \mathrm{~mol} \%$.
\end{abstract}

The culturable and non-culturable bacterial populations from the tap water of four different parts of Seville (Spain) have been studied in order to monitor the microbiological water quality. Four sampling campaigns during a period of 1 year were completed, one each season. A group of slowgrowing, pink-pigmented bacteria was isolated and identified as a Methylobacterium sp.

The genus Methylobacterium was created to include a group of strictly aerobic, Gram-negative, rod-shaped, pinkpigmented, facultatively methylotrophic (PPFM) bacteria that can grow on one-carbon compounds such as formate, formaldehyde and methanol as the sole source of carbon and energy, as well as on a wide range of multi-carbon growth substrates (Green, 1999). The genus Methylobacterium belongs to the $\alpha$-Proteobacteria and has the serine pathway for formaldehyde assimilation. This genus now consists of 18 species: Methylobacterium aminovorans (Urakami et al., 1993), M. aquaticum (Gallego et al., 2005), M. chloromethanicum (McDonald et al., 2001), M. dichloromethanicum (Doronina et al., 2000), M. extorquens (Bousfield \& Green, 1985), M. fujisawaense (Green et al., 1988), M. hispanicum (Gallego et al., 2005), M. lusitanum

Published online ahead of print on 28 January 2005 as DOI 10.1099/ ijs.0.63597-0.

Abbreviation: PPFM, pink-pigmented, facultatively methylotrophic.

The GenBank/EMBL/DDBJ accession number for the 16S rRNA gene sequence of strain GR3 ${ }^{\top}$ is AJ851087.
(Doronina et al., 2002), M. mesophilicum (Green \& Bousfield, 1983), M. nodulans (Jourand et al., 2004), M. organophilum (Patt et al., 1976), M. populi (Van Aken et al., 2004), M. radiotolerans (Green \& Bousfield, 1983), M. rhodesianum (Green et al., 1988), M. rhodinum (Green \& Bousfield, 1983), M. suomiense (Doronina et al., 2002), M. thiocyanatum (Wood et al., 1998) and M. zatmanii (Green et al., 1988).

The type species of the genus Methylobacterium is $M$. organophilum, which was the only PPFM bacterium reported to be capable of growth on methane until the description of a new methane-utilizing species, M. populi. Since $M$. organophilum has lost this ability, and neither the key enzyme of methanotrophic metabolism nor the genes encoding different forms of methane monooxygenase (MMO) have ever been detected in the PPFM bacteria, the methanotrophic ability of $M$. populi must be treated with considerable scepticism (Dedysh et al., 2004).

Members of the genus Methylobacterium are ubiquitous in nature and are thus found in a variety of habitats (Green \& Bousfield, 1981, 1983), including soil, dust, freshwater and lake sediments, leaf surfaces and root nodules, rice grains, air, hospital environments and as contaminants in various products and processes. Species of Methylobacterium have been reported to exhibit resistance to chlorination (Hiraishi et al., 1995) and their presence in drinking water distribution systems is justified. 
Drinking water samples were concentrated by using a tangential flow filtration system (Filtron ${ }^{\circledR}$ ) and plated on Plate Count Agar (Difco) and R2A agar (Difco). Plates were incubated at $28{ }^{\circ} \mathrm{C}$ for 7 days and different morphological colonies were plated in order to obtain pure cultures. We obtained 115 isolates, 32 of which were pink-pigmented. One of these pink-pigmented pure cultures was strain GR $3^{\mathrm{T}}$, which was phenotypically characterized by using the methods described by Doronina et al. (1998). The nutritional features were determined as described by Gallego et al. (2005) by using Biolog Microplates (Biolog).

Chromosomal DNA was isolated and purified according to the methods described by Wilson (1987) and Marmur (1961) and partially modified by Hood et al. (1987). The 16S rRNA gene was amplified by using the universal primers 16F27 and 16R1488 as described by Mellado et al. (1995). Sequencing was performed by NBT-Newbiotechnic using an automated DNA sequencer (model 3100; Applied Biosystems) and an almost-complete nucleotide sequence was determined. Alignment of the 16S rRNA gene sequence was carried out with the ARB software program (Ludwig \& Strunk, 1996). Phylogenetic trees were inferred by using three tree-making algorithms - maximum-parsimony, neighbour-joining (Saitou \& Nei, 1987) and maximumlikelihood. The $\mathrm{G}+\mathrm{C}$ content of genomic DNA was determined by the method of Marmur \& Doty (1962) and by using the equation of Owen \& Hill (1979). DNA-DNA hybridization was carried out following the competition procedure of Johnson (1994), which is described in detail in Mormile et al. (1999). Hybridization temperatures were 60 and $61^{\circ} \mathrm{C}$, which are within the limit of validity for the filter method (De Ley \& Tijtgat, 1970), and the percentage of hybridization was calculated according to Johnson (1994). DNA relatedness values are the mean of three values.

Strain GR $3^{T}$ is a Gram-negative, strictly aerobic rod that measures $1 \cdot 0-1 \cdot 5 \mu \mathrm{m}$ in width by $2 \cdot 0-6 \cdot 0 \mu \mathrm{m}$ in length when grown for $24 \mathrm{~h}$ at $28^{\circ} \mathrm{C}$. Cells are motile. Colonies of strain GR3 ${ }^{\mathrm{T}}$ are circular to slightly irregular in shape, pink in colour and 2-7 $\mathrm{mm}$ in diameter on R2A agar (after 7 days or more); sometimes colonies can have different pink pigmentation. Strain $\mathrm{GR} 3^{\mathrm{T}}$ is a slow-growing organism; no growth occurs in the presence of $1 \% \mathrm{NaCl}$. Differential phenotypic characteristics of strain $\mathrm{GR} 3^{\mathrm{T}}$ are summarized in Table 1.

The almost-complete 16S rRNA gene sequence (approx. $1400 \mathrm{nt}$ ) of strain GR3 ${ }^{\mathrm{T}}$ was determined directly following PCR amplification. In addition, we determined the $16 \mathrm{~S}$ rRNA gene sequence of $M$. aminovorans CCM $4612^{\mathrm{T}}$, the only species of the genus Methylobacterium for which the $16 \mathrm{~S}$ rRNA gene sequence was not available, in order to include it in the phylogenetic analysis. Strain GR3 ${ }^{T}$ exhibited 97.4\% 16S rRNA gene sequence similarity with

Table 1. Differential phenotypic characteristics of $M$. variabile strain $\mathrm{GR}^{\top}$ and other related species of the genus Methylobacterium

Bacteria are identified as: 1, M. variabile $\mathrm{GR}^{\mathrm{T}}$; 2, M. hispanicum CCM $7219^{\mathrm{T}}$ (Gallego et al., 2005); 3, M. aquaticum CCM $7218^{\mathrm{T}}$ (Gallego et al., 2005); 4, M. aminovorans JCM 8240 (Urakami et al., 1993); 5, M. suomiense NCIMB 13778 ${ }^{\mathrm{T}}$ (Doronina et al., 2002); 6, M. lusitanum NCIMB $13779^{\mathrm{T}}$ (Doronina et al., 2002); 7, M. thiocyanatum NCIMB 13651 ${ }^{\mathrm{T}}$ (Wood et al., 1998); 8, M. chloromethanicum NCIMB $13688^{\mathrm{T}}$ (McDonald et al., 2001); 9, M. populi NCIMB $13946^{\mathrm{T}}$ (Van Aken et al., 2004). Symbols: ND, not determined; W, weak; V, variable; + , positive; - , negative.

\begin{tabular}{|c|c|c|c|c|c|c|c|c|c|}
\hline Characteristics & 1 & 2 & 3 & 4 & 5 & 6 & 7 & 8 & 9 \\
\hline \multicolumn{10}{|l|}{ Cells occur: } \\
\hline Singly & + & + & + & + & + & + & ND & ND & + \\
\hline In pairs & + & Rarely & + & Rarely & Rarely & Rarely & ND & ND & + \\
\hline In rosettes & + & - & + & - & - & - & ND & ND & + \\
\hline Cell length $(\mu \mathrm{m})$ & $2-6$ & $2-2 \cdot 5$ & $4 \cdot 5-8$ & $1 \cdot 5-4$ & $1 \cdot 2-2 \cdot 5$ & $1 \cdot 7-2$ & 2 & $2 \cdot 5-3 \cdot 5$ & $1-10$ \\
\hline Cell width $(\mu \mathrm{m})$ & $1-1 \cdot 5$ & $1-1 \cdot 5$ & $1 \cdot 5-1 \cdot 7$ & $0 \cdot 8-1$ & $0 \cdot 8-1$ & $1-1 \cdot 2$ & $0 \cdot 8$ & $0 \cdot 8-1$ & $0 \cdot 8-1$ \\
\hline Pigmentation & Pink (V) & Light pink & Pink to red & Pink or red & Pink & Pink & Pink & Pink & Pink to red \\
\hline Diameter of colonies $(\mathrm{mm})$ & $2-7$ & $1-2$ & $1-2$ & $1-3$ & $0 \cdot 5-1$ & 1 & $\mathrm{ND}$ & $\mathrm{ND}$ & $0 \cdot 1-0 \cdot 2$ \\
\hline Oxidase & - & $+(\mathrm{w})$ & - & + & $+(\mathrm{W})$ & + & $\mathrm{V}$ & ND & + \\
\hline Hydrolysis of starch & $+(\mathrm{w})$ & $+(\mathrm{w})$ & + & - & - & - & ND & ND & ND \\
\hline Upper limit for growth on $\mathrm{NaCl}(\%)$ & 1 & 1 & 1 & 3 & 3 & 3 & ND & ND & 2 \\
\hline \multicolumn{10}{|l|}{ Growth on: } \\
\hline Citrate & + & + & + & - & - & - & + & + & - \\
\hline L-Glutamate & + & + & + & + & - & - & + & + & - \\
\hline D-Glucose & + & - & + & - & + & - & + & - & - \\
\hline D-Xylose & - & - & - & - & - & - & + & - & - \\
\hline Fructose & + & + & + & + & + & + & + & - & + \\
\hline
\end{tabular}




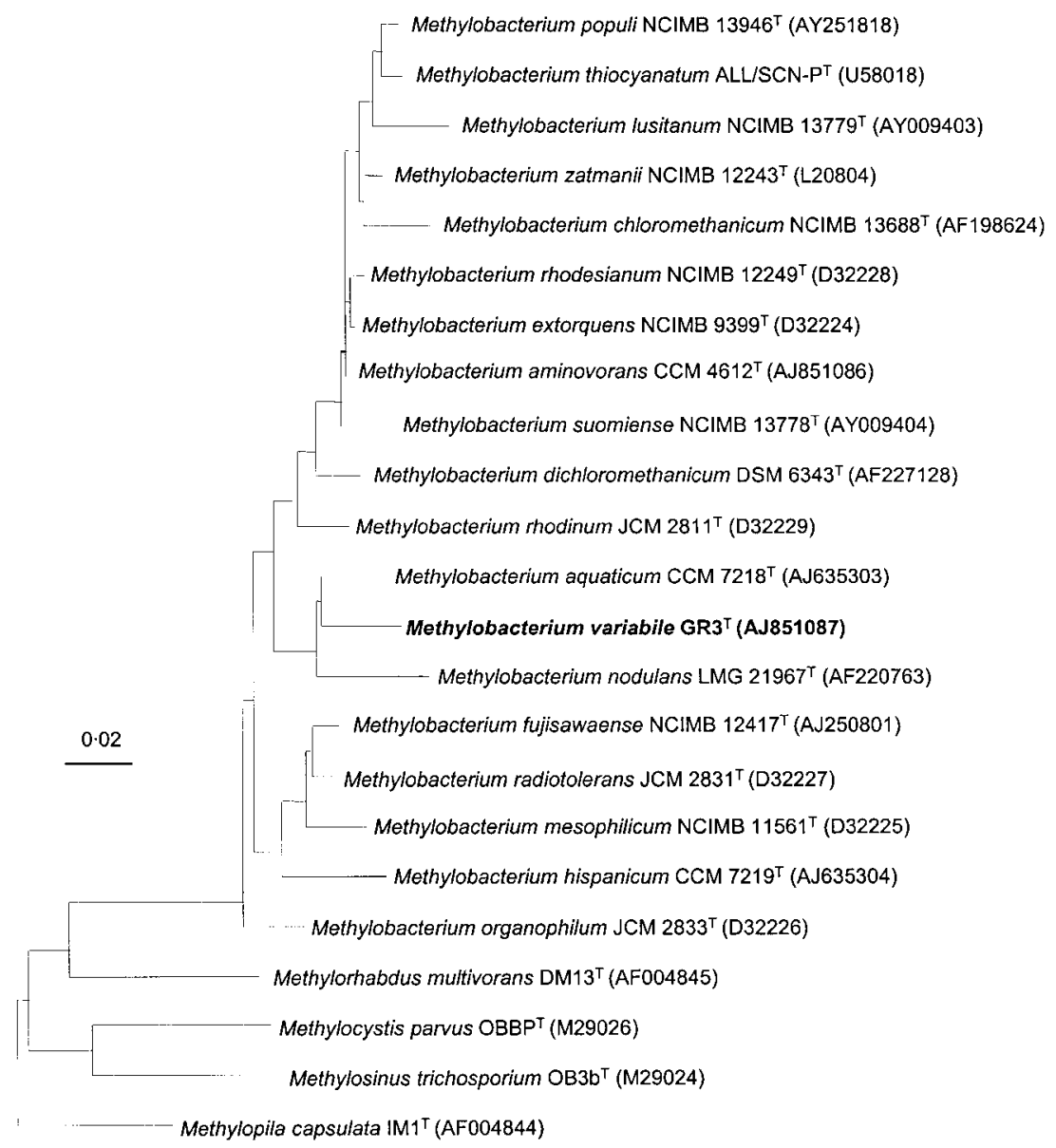

Fig. 1. Phylogenetic tree showing the relationships of strain $\mathrm{GR}^{\top}{ }^{\top}$, species belonging to the genus Methylobacterium and related methylotrophic bacteria. The tree was constructed by using the maximum-parsimony method and was based on a comparison of 16S rRNA gene sequences of approximately $1400 \mathrm{nt}$ in length. Bar, $2 \%$ sequence divergence. respect to $M$. aquaticum and values lower than $95 \cdot 6 \%$ with respect the rest of the species of the genus Methylobacterium (Fig. 1). The DNA G $+\mathrm{C}$ content of strain GR3 ${ }^{\mathrm{T}}$ was $69 \cdot 2 \mathrm{~mol} \%$, which is within the range described for the genus Methylobacterium (Green, 1999). This value is different to that of $M$. aquaticum $(67.7 \mathrm{~mol} \%$ ) (Gallego et al., 2005). Furthermore, to determine the genotypic relatedness between strain $\mathrm{GR}^{\mathrm{T}}$ and $M$. aquaticum CCM $7218^{\mathrm{T}}$, studies of DNA-DNA hybridization were performed. DNA-DNA hybridization values obtained were
30 and $37 \%$, indicating that the new isolate is genotypically different from the type strain of the M. aquaticum. Low DNA-DNA hybridization values $(\leqslant 15 \%)$ were also obtained between strain $\mathrm{GR} 3^{\mathrm{T}}$ and other related Methylobacterium species (Table 2).

On the basis of the data presented above, strain GR3 ${ }^{\mathrm{T}}$ represents a novel species of the genus Methylobacterium, for which we propose the name Methylobacterium variabile sp. nov.

Table 2. Levels of DNA-DNA hybridization between $M$. variabile strain $\mathrm{GR}^{\top}$ and $M$. aquaticum CCM $7218^{\top}$ and other related Methylobacterium species

\begin{tabular}{|c|c|c|}
\hline \multirow[t]{2}{*}{ Source of unlabelled DNA } & \multicolumn{2}{|c|}{ Relatedness (\%) with ${ }^{3} \mathrm{H}$-labelled DNA from strain } \\
\hline & $\mathrm{GR}^{\mathrm{T}}$ & CCM $7218^{\mathrm{T}}$ \\
\hline M. variabile $\mathrm{GR} 3^{\mathrm{T}}$ & 100 & 37 \\
\hline M. aquaticum $\mathrm{CCM} 7218^{\mathrm{T}}$ & 30 & 100 \\
\hline M. aminovorans $\mathrm{CCM} 4612^{\mathrm{T}}$ & 4 & 18 \\
\hline M. extorquens NCIMB $9399^{\mathrm{T}}$ & 15 & 18 \\
\hline M. radiotolerans CCM $4464^{\mathrm{T}}$ & 5 & 25 \\
\hline M. nodulans LMG $21967^{\mathrm{T}}$ & 13 & ND \\
\hline
\end{tabular}

ND, Not determined. 


\section{Description of Methylobacterium variabile sp. nov.}

Methylobacterium variabile (L. neut. adj. variabile variable).

Gram-negative rods, $1 \cdot 0-1 \cdot 5 \mu \mathrm{m} \times 2 \cdot 0-6 \cdot 0 \mu \mathrm{m}$, occurring singly in pairs or in rosettes. Cells are motile, non-sporeforming and strictly aerobic. Colonies are pink, circular to slightly irregular and $2-7 \mathrm{~mm}$ in diameter after 7 days at $28^{\circ} \mathrm{C}$ on R2A agar; sometimes colonies have different pink pigmentations. Slow-growing; does not grow in the presence of $1.0 \% \mathrm{NaCl}$ or higher. Growth occurs at $20-30{ }^{\circ} \mathrm{C}$ (optimal temperature $28^{\circ} \mathrm{C}$ ) and at $\mathrm{pH} 5 \cdot 0-8 \cdot 0$ (optimal pH 6.0). Catalase- and urease-positive. Oxidase-negative. Indole, methyl red and Voges-Proskauer are negative. Starch is weakly hydrolysed. Tween 80 is hydrolysed. Gelatin, casein, aesculin and DNA are not hydrolysed. Hydrogen sulfide is not produced. Simmons' citrate test is positive. Nitrate is reduced to nitrite. Acid is produced oxidatively from $\mathrm{D}$-arabinose, but not from D-glucose, D-galactose, D-mannose or maltose. Methanol, formate and formaldehyde are utilized as sole carbon sources. Ammonium sulfate, nitrate, aspartate and glutamate are utilized as sole nitrogen sources. The following compounds are utilized as sole carbon and energy sources (Biolog): D-fructose, L-fucose, D-galactose, D-gluconic acid, $\alpha$-D-glucose, acetic acid, $\alpha$-hydroxybutyric acid, $\beta$ hydroxybutyric acid, $\gamma$-hydroxybutyric acid, $\alpha$-ketoglutaric acid, L-lactic acid, L-malic acid, mono-methyl succinate, propionic acid, pyruvic acid, succinamic acid, succinic acid, L-asparagine and L-glutamic acid. The following compounds are not utilized as sole carbon and energy sources (Biolog): Tween 40, Tween 80, $\alpha$-cyclodextrin, $\beta$-cyclodextrin, dextrin, glycogen, inulin, mannan, $N$-acetylD-glucosamine, $\mathrm{N}$-acetyl-D-mannosamine, amygdalin, Larabinose, D-arabitol, arbutin, cellobiose, D-galacturonic acid, gentibiose, $m$-inositol, $\alpha$-D-lactose, lactulose, maltose, maltotriose, D-mannitol, D-mannose, D-melezitose, Dmelibiose, methyl $\alpha$-D-galactoside, 3-methyl glucose, methyl $\alpha$-D-glucoside, methyl $\beta$-D-glucoside, methyl $\alpha$-Dmannoside, palatinose, D-psicose, D-raffinose, L-rhamnose, D-ribose, salicin, sedoheptulosan, D-sorbitol, stachyose, sucrose, D-tagatose, D-trehalose, turanose, xylitol, Dxylose, $p$-hydroxyphenyl acetic acid, $\alpha$-ketovaleric acid, lactamide, D-lactic acid methyl ester, D-malic acid, methyl pyruvate, alaninamide, $\mathrm{N}$-acetyl-L-glutamic acid, D-alanine, L-alanine, glycyl-L-glutamic acid, L-alanyl-glycine, Lpyroglutamic acid, L-serine, putrescine, 2,3-butanediol, glycerol, adenosine, $2^{\prime}$-deoxyadenosine, inosine, thymidine, uridine, adenosine $5^{\prime}$-monophosphate, thymidine $5^{\prime}$ monophosphate, uridine $5^{\prime}$-monophosphate, fructose 6phosphate, glucose 1-phosphate, glucose 6-phosphate and DL- $\alpha$-glycerol phosphate.

The type strain is GR3 ${ }^{\mathrm{T}}\left(=\mathrm{DSM} 16961^{\mathrm{T}}=\mathrm{CCM} 7281^{\mathrm{T}}=\right.$ CECT $7045^{\mathrm{T}}$ ), which was isolated from drinking water. The DNA $\mathrm{G}+\mathrm{C}$ content of the type strain is $69 \cdot 2 \mathrm{~mol} \%$.

\section{Acknowledgements}

V.G. was supported by a fellowship from the Spanish Ministerio de Educación y Ciencia. This work was supported by grants from the Quality of Life and Management of Living Resources Programme of the European Commission (QLK3-CT-2002-01972), Spanish Ministerio de Ciencia y Tecnología (BMC2003-01344) and from the Junta de Andalucía.

\section{References}

Bousfield, I. J. \& Green, P. N. (1985). Reclassification of bacteria of the genus Protomonas Urakami and Komagata 1984 in the genus Methylobacterium (Patt, Cole, and Hanson) emend. Green and Bousfield 1983. Int J Syst Bacteriol 35, 209.

Dedysh, S. N., Dunfield, P. F. \& Trotsenko, Y. A. (2004). Methane utilization by Methylobacterium species: new evidence but still no proof for an old controversy. Int J Syst Evol Microbiol 54, 1919-1920.

De Ley, J. \& Tijtgat, R. (1970). Evaluation of membrane filter methods for DNA-DNA hybridization. Antonie van Leeuwenhoek 36, 461-474.

Doronina, N. V., Trotsenko, Y. A., Krausova, V. I., Boulygina, E. S. \& Tourova, T. P. (1998). Methylopila capsulata gen. nov., sp. nov., a novel non-pigmented aerobic facultatively methylotrophic bacterium. Int J Syst Bacteriol 48, 1313-1321.

Doronina, N. V., Trotsenko, Y. A., Tourova, T. P., Kuznetsov, B. B. \& Leisinger, T. (2000). Methylopila helvetica sp. nov. and Methylobacterium dichloromethanicum sp. nov. - novel aerobic facultatively methylotrophic bacteria utilizing dichloromethane. Syst Appl Microbiol 23, 210-218.

Doronina, N. V., Trotsenko, Y. A., Kuznetsov, B. B., Tourova, T. P. \& Salkinoja-Salonen, M. S. (2002). Methylobacterium suomiense sp. nov. and Methylobacterium lusitanum sp. nov., aerobic, pinkpigmented, facultatively methylotrophic bacteria. Int J Syst Evol Microbiol 52, 773-776.

Gallego, V., Garcia, M. T. \& Ventosa, A. (2005). Methylobacterium hispanicum sp. nov. and Methylobacterium aquaticum sp. nov., isolated from drinking water. Int J Syst Evol Microbiol 55, 281-287.

Green, P. N. (1999). The genus Methylobacterium. In The Prokaryotes: an Evolving Electronic Resource for the Microbiological Community, 3rd edn, release 3.0, 21 May 1999. Edited by M. Dworkin et al. New York: Springer-Verlag (http://link.springer-ny. com/link/service/books/10125/).

Green, P. N. \& Bousfield, I. J. (1981). The taxonomy of pinkpigmented facultatively methylotrophic bacteria. In Microbial Growth on $C_{1}$-Compounds, pp. 285-293. Edited by H. Dalton. London: Heyden \& Son.

Green, P. N. \& Bousfield, I. J. (1983). Emendation of Methylobacterium Patt, Cole, and Hanson 1976; Methylobacterium rhodinum (Heumann 1962) comb. nov. corrig.; Methylobacterium radiotolerans (Ito and Iizuka 1971) comb. nov., corrig.; and Methylobacterium mesophilicum (Austin and Goodfellow 1979) comb. nov. Int J Syst Bacteriol 33, 875-877.

Green, P. N., Bousfield, I. J. \& Hood, D. (1988). Three new Methylobacterium species: M. rhodesianum sp. nov., M. zatmanii sp. nov., and M. fujisawaense sp. nov. Int J Syst Bacteriol 38, 124-127.

Hiraishi, A., Furuhata, K., Matsumoto, A., Koike, K. A., Fukuyama, M. \& Tabuchi, K. (1995). Phenotypic and genetic diversity of chlorine-resistant Methylobacterium strains isolated from various environments. Appl Environ Microbiol 61, 2099-2107. 
Hood, D. W., Dow, C. S. \& Green, P. N. (1987). DNA:DNA hybridization studies on the pink-pigmented facultative methylotrophs. J Gen Microbiol 38, 709-720.

Johnson, J. L. (1994). Similarity analysis of DNAs. In Methods for General and Molecular Bacteriology, pp. 655-681. Edited by P. Gerhardt, R. G. E. Murray, W. A. Wood \& N. R. Krieg. Washington, DC: American Society for Microbiology.

Jourand, P., Giraud, E., Béna, G., Sy, A., Willems, A., Gillis, M., Dreyfus, B. \& de Lajudie, P. (2004). Methylobacterium nodulans sp. nov., for a group of aerobic, facultatively methylotrophic, legume root-nodule-forming and nitrogen-fixing bacteria. Int J Syst Evol Microbiol 54, 2269-2273.

Ludwig, W. \& Strunk, O. (1996). ARB - a software environment for sequence data (http://www.mikro.biologie.tu-muenchen.de).

Marmur, J. (1961). A procedure for the isolation of deoxyribonucleic acid from micro-organisms. J Mol Biol 3, 208-218.

Marmur, J. \& Doty, P. (1962). Determination of the base composition of deoxyribonucleic acid from its thermal denaturation temperature. J Mol Biol 5, 109-118.

McDonald, I. R., Droning, N. V., Trotsenko, Y. A., McAnulla, C. \& Murrell, J. C. (2001). Hyphomicrobium chloromethanicum sp. nov. and Methylobacterium chloromethanicum sp. nov., chloromethaneutilizing bacteria isolated from a polluted environment. Int J Syst Evol Microbiol 51, 119-122.

Mellado, E., Moore, E. R. B., Nieto, J. J. \& Ventosa, A. (1995). Phylogenetic inferences and taxonomic consequences of $16 \mathrm{~S}$ ribosomal DNA sequence comparison of Chromohalobacter marismortui, Volcaniella eurihalina, and Deleya salina, and reclassification of V. eurihalina as Halomonas eurihalina comb. nov. Int J Syst Bacteriol 45, 712-716.
Mormile, M. R., Romine, M. F., García, M. T., Ventosa, A., Bailey, T. J. \& Peyton, B. M. (1999). Halomonas campisalis sp. nov., a denitrifying, moderately haloalkaliphilic bacterium. Syst Appl Microbiol 22, 551-558.

Owen, R. J. \& Hill, L. R. (1979). The estimation of base compositions, base pairing and genome size of bacterial deoxyribonucleic acids. In Identification Methods for Microbiologists, 2nd edn, pp. 217-296. Edited by F. A. Skinner \& D. W. Lovelock. London: Academic Press.

Patt, T. E., Cole, G. C. \& Hanson, R. S. (1976). Methylobacterium, a new genus of facultatively methylotrophic bacteria. Int $J$ Syst Bacteriol 26, 226-229.

Saitou, N. \& Nei, M. (1987). The neighbor-joining method: a new method for reconstructing phylogenetic trees. Mol Biol Evol 4, 406-425.

Urakami, T., Araki, H., Suzuki, K. I. \& Komogata, K. (1993). Further studies of the genus Methylobacterium and description of Methylobacterium aminovorans sp. nov. Int J Syst Bacteriol 43, 504-513.

Van Aken, B., Peres, C. M., Lafferty Doty, S., Yoon, J. M. \& Schnoor, J. L. (2004). Methylobacterium populi sp. nov., a novel aerobic, pinkpigmented, facultatively methylotrophic, methane-utilizing bacterium isolated from poplar trees (Populus deltoides $\times$ nigra DN34). Int J Syst Evol Microbiol 54, 1191-1196.

Wilson, K. (1987). Preparation of genomic DNA from bacteria. In Current Protocols in Molecular Biology, pp. 2.4.1-2.4.2. Edited by F. M. Ausubel, R. Brent, R. E. Kingston, D. D. Moore, J. G. Seidman, J. A. Smith \& K. Struhl. New York: Wiley.

Wood, A. P., Kelly, D. P., McDonald, I. R., Jordan, S. L., Morgan, T. D., Khan, S., Murrell, J. C. \& Borodina, E. (1998). A novel pink-pigmented facultative methylotroph, Methylobacterium thiocyanatum sp. nov., capable of growth on thiocyanate or cyanate as sole nitrogen sources. Arch Microbiol 169, 148-158. 